\title{
Incidence and prevalence of diabetes mellitus in the Americas
}

\author{
Alberto Barceló ${ }^{1}$ and Swapnil Rajpathak ${ }^{1}$
}

ABSTRACT Objective. To present the incidence and prevalence of diabetes mellitus in the Americas as found through a thorough review of published information on the subject.

Methods. Data were obtained through a comprehensive review using the MEDLINE and BIREME bibliographical databases. In addition, government publications, conference reports, and meeting documents were identified by contacting government and nongovernmental organizations and other institutions. Incidence and prevalence rates were adjusted by age and sex, when possible, by the direct method using the world Segi population as the standard. The 95\% confidence intervals were calculated using the Poisson distribution or the normal distribution.

Results. Diabetes mellitus represents a major public health problem in the Americas, and there is evidence that its prevalence is increasing in some countries.

Conclusions. Given that most Latin American and Caribbean nations are experiencing a demographic transition, it is expected that the prevalence of diabetes will continue to increase rapidly in the near future. Despite the economic constraints faced by the countries of the Americas, there is a clear need for more efforts in the area of diabetes prevention and control.

Key words Diabetes, prevalence, Region of the Americas.

Diabetes mellitus is a chronic metabolic disease characterized by hyperglycemia and by disturbances of carbohydrate, fat, and protein metabolism. It is associated with an absolute or relative deficiency in the secretion and/or action of the hormone insulin. In the Americas, the number of people with diabetes mellitus was estimated at 35 million in 2000 and is expected to increase to 64 million by 2025 . Whereas currently $52 \%$ of these people from the Americas live in Latin America and the Caribbean, by 2025 the per-

\footnotetext{
1 Pan American Health Organization, Washington, D.C., United States of America. Send correspondence to: Alberto Barceló, PAHO, 525 Twentythird Street, N.W., Washington, D.C. 20037-2895, United States of America; telephone: (202) 9743589; fax: (202) 974-3643; e-mail: barceloa@paho.org
}

centage will have reached $62 \%$, representing 40 million persons (1). This increase results from multiple factors involved in lifestyle changes related to modern life such as the decrease in physical activities and the predominance of hypercaloric diets and the resulting obesity. Also playing a major part is the aging process of the population in developing countries. Given these various factors, an increase in diabetes mellitus caseload will be more evident in developing countries.

Diabetes increases the risk of premature death mainly due to an increased risk of cardiovascular events. In addition, people suffering from diabetes have a greater risk of developing visual problems and renal disease as well as undergoing lower-extremity amputations.

\section{Diagnostic criteria and classification}

In 1985 the World Health Organization (WHO) published updated criteria for the diagnosis of diabetes mellitus (2). More recently, in 1997, the American Diabetes Association (ADA) published new diagnostic criteria lowering the fasting plasma glucose concentration for the diagnosis of the disease from $\geq 140 \mathrm{mg} / \mathrm{dL}$ to $\geq 126 \mathrm{mg}$ / dL. WHO published similar criteria for the diagnosis of diabetes in 1999 after a WHO expert committee reviewed the issue and reached the same conclusions as the $\operatorname{ADA}(3,4)$. A new cutoff point for plasma glucose concentration 2 hours after an oral dose of $75 \mathrm{mg}$ of glucose was established because of the proven increase in the prevalence of diabetes-related microvascular com- 
plications (e.g., retinopathy and nephropathy) among people with values of $\geq 200 \mathrm{mg} / \mathrm{dL}$. The previous fasting glucose cutoff point of $140 \mathrm{mg} / \mathrm{dL}$ identified subjects with more severe hyperglycemia than the present 2hour cutoff point of $200 \mathrm{mg} / \mathrm{dL}$. Thus, by lowering the fasting cutoff point to $126 \mathrm{mg} / \mathrm{dL}$, it becomes possible to identify subjects whose hyperglycemia is roughly equivalent to that of subjects who test positive on the 2hour glucose tolerance test.

In addition, in 2000 the ADA recommended using a fasting plasma glucose of $\geq 126 \mathrm{mg} / \mathrm{dL}$ as the sole criterion for diagnosing diabetes in epidemiologic studies (5). However, WHO still recommends the 2-hour oral glucose tolerance test (OGTT) as the single best diagnostic criterion for such studies, but if this test cannot be performed because of logistic or economic reasons, the fasting plasma glucose alone, as established by the ADA, may be used instead as the basis for the diagnosis (4). According to the updated WHO classification of diabetes, there are two major forms of the disease: type 1 and type 2 (formerly, respectively, insulin-dependent diabetes mellitus (IDDM) and non-insulin dependent diabetes mellitus (NIDDM)). Type 1 diabetes appears mainly in children and young adults, is characterized by an acute onset, and requires insulin treatment. Type 2 diabetes appears insidiously, mainly in adults, and can be treated in a variety of ways, including with a dietary regimen, oral hypoglycemic agents, insulin, or a combination of these. Type 2 diabetes is the most common form of the disease, accounting for about $85 \%$ to $90 \%$ of all cases. It has been linked to potentially modifiable risk factors such as obesity, lack of exercise, and a hypercaloric diet. As many studies have demonstrated, in most populations there are many people with undiagnosed type 2 diabetes (6-8). Another important subcategory under type 2 of the disease is gestational diabetes, which is defined as glucose intolerance (of any degree) diagnosed for the first time during pregnancy (9). It is estimated that about $4 \%$ of pregnant women develop this form of diabetes.
The objective of this paper is to present the incidence and prevalence of diabetes mellitus in the Americas as found through a comprehensive review of published information on the subject.

\section{MATERIALS AND METHODS}

We conducted a comprehensive literature search to identify results from apparently unbiased populationbased diabetes surveys and registries. The search was conducted using the MEDLINE and BIREME bibliographic databases. The terms used in the search were "diabetes incidence," "diabetes prevalence," "diabetes survey," and "diabetes registry." Literature that was not indexed, such as gray papers, government publications, and conference proceedings, was obtained by contacting government offices, nongovernmental organizations, scientific and diabetes associations, and the country offices of the Pan American Health Organization (PAHO). Incidence and prevalence rates were adjusted by age and sex, when possible, by the direct method, using the world Segi population as the standard (10). The 95\% confidence intervals ( $95 \%$ CIs) were calculated using the Poisson distribution or the normal distribution, as described by King et al. (11). Published articles including diabetes estimates and projections were also reviewed.

\section{RESULTS}

\section{Incidence and prevalence of childhood diabetes}

The worldwide incidence of type 1 diabetes has been evaluated during the last 20 years through the DiaMond Project (12-14), which oversees the maintenance of registries of children with diabetes around the world. About 24 of these registries operate in the Region of the Americas. There have been other publications in the Region on the incidence of type 1 diabetes, mainly in children under 15 years of age. Since most registries rely on more than one source of information, we assessed their completeness. The subsections below summarize the data for the specific subregions and countries of the Americas, with Table 1 providing additional details.

North America. Amos et al. (15) estimated the prevalence of type 1 diabetes in North America in 1997 among children under 15 years of age at 53.4 per 10000 population. For that year, prevalence rates ranged from 8.3 per 10000 population in the United States to 0.3 per 10000 in Mexico. Prince Edward Island, Canada, has reported the highest incidence of type 1 diabetes in children in the Americas $(12,13)$. The Montreal, Canada, registry reported an incidence rate of 10.1 per 100000 for the period 1975-1981 (16). Three registries from the United States were included in the DiaMond report of 2000 , all of them covering the period of 1990-1994: Allegheny County, Pennsylvania (incidence of 17.8 per 100000 population); Jefferson, Alabama (incidence of 15.0 per 100 000), and Chicago, Illinois (incidence of 11.7 per 100000 population). A registry in Rochester, Minnesota, reported a childhood incidence rate of 20.8 per 100000 in 1980 (14).

Caribbean. In the Caribbean, the estimated prevalence rate of type 1 diabetes in children under 15 years of age ranged from 6.4 per 10000 in Puerto Rico to 0.3 per 10000 in Haiti in 1997 (Table 1). A high incidence rate has been consistently reported by Puerto Rico (19). The lowest childhood incidence in the Caribbean was reported for Barbados.

Antigua, Barbados, Dominica, Saint. Croix, Saint Thomas, and Tortola Island reported on the incidence of type 1 diabetes among those aged 0 to 19 years. The highest incidence rate was reported for Saint Croix, and the lowest was reported for Saint Kitts (20).

Central America. The estimated prevalence of type 1 diabetes among chil- 
TABLE 1. Incidence and estimated prevalence of type 1 diabetes mellitus in children in Latin America and the Caribbean

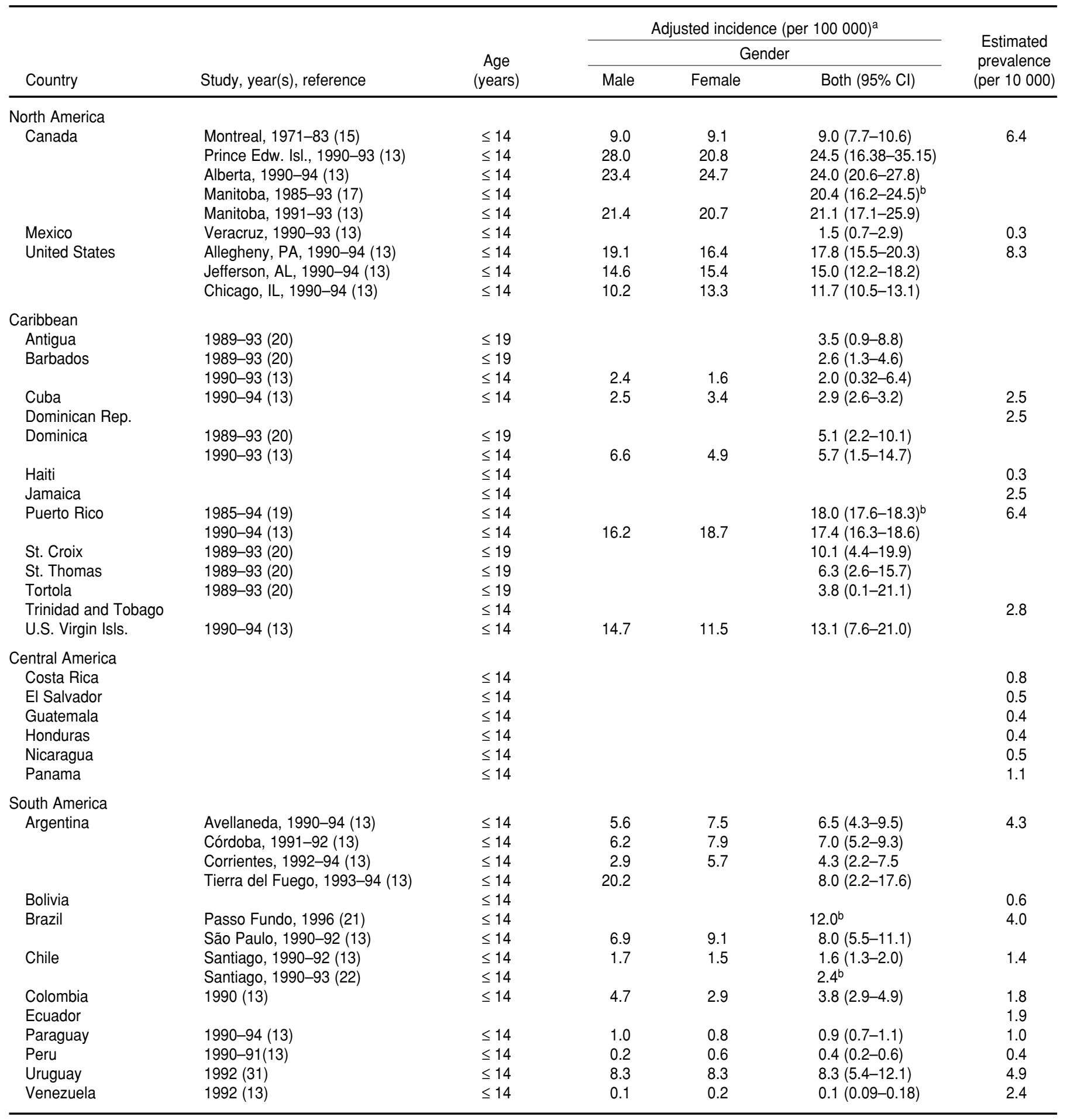

a Using the world population as the standard (10).

${ }^{b}$ Crude rates.

dren under the age of 15 years ranged from 1.1 per 10000 population in Panama to 0.4 per 10000 in Guatemala and Honduras in 1997 (Table 1).
South America. In South America in 1997, 31000 children under 15 years of age were estimated to have type 1 diabetes (15). The greatest prevalence was estimated for Uruguay (4.9 per 10 000), while the lowest was estimated for Peru (0.4 per 10 000) (Table $1)$. The highest incidence of type 1 
TABLE 2. Characteristics of diabetes surveys of adults conducted in the Americas

\begin{tabular}{|c|c|c|c|c|c|c|c|}
\hline Country & Population, reference & Year & $\begin{array}{l}\text { Sample } \\
\text { size }\end{array}$ & $\begin{array}{c}\text { Age } \\
\text { (years) }\end{array}$ & $\begin{array}{c}\text { Diagnostic } \\
\text { test }^{\mathrm{a}}\end{array}$ & $\begin{array}{l}\text { Glucose } \\
\text { load (g) }\end{array}$ & Criteria \\
\hline \multicolumn{8}{|l|}{ North America } \\
\hline Canada & Native, Lac Simon (25) & 1995 & 168 & $30-64$ & OGTT & 75 & WHO 1985 \\
\hline \multirow[t]{2}{*}{ Mexico } & Mexico City (26) & 1992 & 646 & $35-64$ & OGTT & 75 & WHO 1985 \\
\hline & Mexico City (27) & 1994 & 805 & $20-90$ & FPG & - & $140 \mathrm{mg} / \mathrm{dL}$ \\
\hline United States & Three ethnic groups (28) & $1988-94$ & 2844 & $40-74$ & OGTT & 75 & WHO 1985 \\
\hline \multicolumn{8}{|l|}{ Caribbean } \\
\hline Barbados & Bridgetown (31) & 1993 & 464 & $40-79$ & FPG & - & $140 \mathrm{mg} / \mathrm{dL}$ \\
\hline \multirow[t]{2}{*}{ Cuba } & Santiago C (32) & 1987 & 500 & $15+$ & OGTT & 75 & WHO 1985 \\
\hline & Havana (33) & 1998 & 250 & $25+$ & OGTT & 75 & WHO 1985 \\
\hline Guadeloupe & Guadeloupe (34) & 1989 & 1049 & $18+$ & OGTT & 75 & WHO 1985 \\
\hline Jamaica & Jamaica (6) & 1995 & 2109 & $15+$ & OGTT & 75 & WHO 1985 \\
\hline \multicolumn{8}{|l|}{ South America } \\
\hline Argentina & Avellaneda (39) & 1979 & 596 & $20-69$ & OGTT & 50 & $150 \mathrm{mg} / \mathrm{dL}$ \\
\hline Bolivia & Four cities (8) & 1998 & 2500 & $25+$ & OGTT & 75 & WHO 1985 \\
\hline \multirow[t]{4}{*}{ Brazil } & Nine cities (40) & $1986-88$ & 21847 & $30-69$ & OGTT & 75 & WHO 1985 \\
\hline & Rio de Janeiro (41) & $1986-88$ & 2051 & $30-69$ & OGTT & 75 & WHO 1985 \\
\hline & São Paulo, Issei (42) & 1996 & 238 & $40-79$ & OGTT & 75 & WHO 1985 \\
\hline & São Paulo, Nisei (42) & 1996 & 292 & $40-79$ & OGTT & 75 & WHO 1985 \\
\hline \multirow[t]{5}{*}{ Chile } & Santiago (45) & 1979 & 1110 & $20+$ & OGTT & 50 & $150 \mathrm{mg} / \mathrm{dL}$ \\
\hline & Valparaíso (44) & 1997 & 3120 & $25-64$ & OGTT & 75 & WHO 1985 \\
\hline & Mapuche (45) & 1983 & 510 & $20+$ & OGTT & 75 & WHO 1985 \\
\hline & Mapuche (46) & 1998 & 319 & $20+$ & OGTT & 75 & WHO 1985 \\
\hline & Aymara (47) & 1998 & 196 & $20+$ & OGTT & 75 & WHO 1985 \\
\hline Colombia & Urban (7) & 1993 & 670 & $30+$ & OGTT & 75 & WHO 1985 \\
\hline Paraguay & Urban (48) & 1992 & 1094 & $20-74$ & OGTT & 75 & WHO 1985 \\
\hline
\end{tabular}

a Diagnostic tests: $\mathrm{OGTT}=$ oral glucose tolerance test; $\mathrm{FPG}=$ fasting plasma glucose .

${ }^{b}$ Glucose load: $1 \mathrm{~g} / \mathrm{kg}$ of body weight.

${ }^{c}$ Diagnostic criteria: $1 \mathrm{~h}$ after glucose load, blood glucose of $180 \mathrm{mg} / \mathrm{dL} ; 1.5 \mathrm{~h}$ after glucose load, blood glucose of $160 \mathrm{mg} / \mathrm{dL}$, and $2 \mathrm{~h}$ after glucose load, blood glucose of $135 \mathrm{mg} / \mathrm{dL}$.

diabetes among children was also reported in Uruguay (8.3 per 100000$)$, while the lowest was reported in Venezuela (0.1 per 100 000). Tierra del Fuego, Argentina, reported an incidence rate of 20.2 per 100000 among boys, but this rate was based on only 4 cases, and no case was reported among girls, for a total incidence of 8.0 per 100000 for both sexes. In the Americas, only the Colombian registry reported statistically significant differences between boys and girls (4.7 vs. 2.9 per 100000 , respectively).

\section{Diabetes in adult populations}

Most countries in Latin America and the Caribbean do not carry out epidemiological surveillance for diabetes in adults. Therefore, information on the prevalence of this type of diabetes in those nations is limited. Some surveys have been conducted but not usually as part of national or regional policies for diabetes surveillance. Accordingly, surveys of diabetes carried out in Latin America and the Caribbean have been sporadic, and they differ in important methodological features such as selection of the study population, age, sampling method, and diagnostic criteria. For this reason, comparison between studies is often problematic. Nevertheless, diabetes surveys provide the only data available on the epidemiology of this disease. The characteristics of the diabetes surveys conducted in the Americas are shown in Table 2. Most of the selected studies used the oral glucose tolerance test (OGTT) as a diagnostic test along with the WHO 1985 diagnostic criteria (2). The largest survey conducted in the Americas, which in- 
cluded 21847 persons, was carried out in Brazil in 1986-1988.

North America. The most recent estimate of the prevalence of diagnosed diabetes among adults in Canada, as revealed by the 1996-1997 National Population Health Survey, was 3.2\% (24). In the United States, the National Health and Nutrition Examination Survey (NHANES) periodically conducts a cross-sectional nationally representative survey among participants aged 20 years and over who complete a household interview. As part of this survey, a subsample of 2844 subjects between the ages of 40 and 74 years underwent an OGTT between 1988 and 1994. Based on WHO diagnostic criteria, the prevalence rate of diabetes (previously and newly diagnosed) increased from $11.4 \%$ in $1976-1980$ to $14.3 \%$ in $1988-1994$ (28). Diabetes prevalence rates for Mexican-Americans were twice as high as for non-Hispanic whites. About 20\% of non-Hispanic blacks in the United States were affected by diabetes; the prevalence rate in this group was the second highest after that of MexicanAmericans (Table 3). The Pima Indians from the state of Arizona have shown the highest prevalence of diabetes in the Americas and one of the highest in the world. The reported age- and sex-adjusted rate for this group was 21.1\% in 1978 (29). After adjusting for age and sex with the world population as the standard, the prevalence of diabetes for Pima Indians 25 years of age or older in 19821990 was $51.4 \%$ overall for males and females (30).

Caribbean. We found no reports showing survey results for the Dominican Republic, Haiti, Martinique, the Netherlands Antilles, and Puerto Rico. Among the surveys found that used OGTT as the diagnostic test, the highest crude prevalence rate of diabetes was reported by Jamaica in 1995, $17.9 \%$. The lowest crude rate $(4.6 \%)$ was reported in Santiago, Cuba, but a higher prevalence was reported more recently in Havana (11.8\%). All Caribbean countries with surveys found had age- and sex-adjusted prevalence rates for diabetes of over $10 \%$.

In Barbados, a diabetes survey that employed a fasting plasma glucose of $>140 \mathrm{mg} / \mathrm{dL}$ as the diagnostic criterion found a crude prevalence rate of $17 \%$; after age and sex adjustment, that rate dropped to $16.4 \%$.

Central America. No publications showing the prevalence of diabetes in Central America and meeting our methodological requirements for inclusion could be found. The 1998 National Household Survey in Costa Rica reported a prevalence rate of diagnosed diabetes among adults of $2.8 \%$ in the general population and $9.4 \%$ among those aged 40 years or over (37).

South America. No published reports were found showing results of glucose tolerance tests in Ecuador and Guyana. Among the surveys using OGTT and the WHO diagnostic criteria, the highest crude prevalence rate of diabetes was reported among Japanese immigrants to Brazil (Issei (second generation), $16.2 \%$; Nisei (first generation), $12.6 \%$ ). The adjusted prevalence rate for East Indians in Suriname $(12.7 \%)$ was the highest in South America, but this study used an oral glucose load of $50 \mathrm{~g}$ for the 2-hour test and a cutoff blood glucose value of $180 \mathrm{mg} / \mathrm{dL}$. Most South American studies reported diabetes prevalence rates of between $6 \%$ and $9 \%$. The lowest crude prevalence rate was reported for the Aymara Indians in Chile $(1.5 \%)$. The Mapuche Indians from Chile showed a low prevalence rate $(1.0 \%)$ in 1985 , but a more recent survey reported a prevalence rate of $4.1 \%$ in this group. A study conducted in Uruguay and Venezuela in 1966, using an oral load of $1 \mathrm{~g}$ of glucose per $\mathrm{kg}$ of body weight and a cutoff point of $150 \mathrm{mg} / \mathrm{dL}$, reported prevalence rates of $6.9 \%$ and $7.3 \%$ for these countries, respectively.

\section{Adjusted prevalence rates among subjects aged 35 to 64 years}

Among people 35 to 64 years old, in the countries for which data were available, the prevalence of diabetes was highest in Jamaica (15.6\%) (Table 4). Mexico, Trinidad and Tobago, and Bolivia also presented prevalence rates over $10 \%$. Moderate prevalence rates $(3 \%-10 \%)$ were observed in the rest of the countries. The lowest prevalence rate was observed in La Plata, Argentina $(3.0 \%)$. Jamaican, Mexican, and Chilean males had prevalence rates of over $10 \%$. Moderate prevalence rates for diabetes were observed in males from the rest of the countries. Women were at higher risk in Jamaica, Mexico, Trinidad and Tobago, and Bolivia, while Brazilian, Colombian, Paraguayan, and Surinamese women had moderate prevalence rates $(3 \%-9 \%)$. Argentine women presented the lowest prevalence rate $(2.6 \%)$.

\section{DISCUSSION}

As evidenced by the data presented in this article, in some areas of the Americas there is a pronounced lack of information regarding diabetes. Nonetheless, it is obvious that diabetes represents a major public health problem for the Americas, and there is evidence that its prevalence is increasing (33, 46). Given that most Latin American and Caribbean countries are experiencing a demographic transition, the prevalence of diabetes is expected to increase rapidly in the near future.

We found great variability in the incidence of type 1 diabetes in the Americas, ranging from 24 per 100000 in some areas of Canada in 1990-1993 to 0.2 per 100000 in Venezuela in 1992. In 1997, the prevalence of type 1 diabetes among persons under 15 years of age in the Americas was estimated at 88000 . Of these children, $35000(40 \%)$ lived in Latin America and the Caribbean. Although type 1 diabetes appears to be uncommon in most Latin American and Caribbean (LAC) countries, the increased related mortality 
TABLE 3. Survey results showing the prevalence (\%) of diabetes mellitus among adult populations of the Americas

\begin{tabular}{|c|c|c|c|c|c|c|c|c|c|c|}
\hline \multirow[b]{2}{*}{ Country } & \multirow[b]{2}{*}{ Population, reference } & \multicolumn{3}{|c|}{ Crude rates $(95 \% \mathrm{Cl})$} & \multicolumn{6}{|c|}{ Adjusted rates ${ }^{\mathrm{a}}(95 \% \mathrm{Cl})^{\mathrm{b}}$} \\
\hline & & Male & Female & Both & & Male & & Female & & Both \\
\hline \multicolumn{11}{|l|}{ North America } \\
\hline \multirow[t]{2}{*}{ Canada } & Native, River Desert (25) & 17.6 & 16.3 & - & 16.3 & $(7.9-24.7)$ & 16.3 & $(9.0-23.6)$ & & \\
\hline & Native, Lac Simon (25) & 22.2 & 44.3 & - & 23.9 & $(12.9-34.9)$ & 48.6 & $(38.4-58.8)$ & & \\
\hline \multirow[t]{2}{*}{ Mexico } & Mexico City (26) & 10.6 & 14.8 & 13.0 & 11.9 & $(8.0-17.2)$ & 17.9 & $(13.5-23.5)$ & 14.9 & $(11.9-18.6)$ \\
\hline & Mexico City (27) & 6.6 & 11.0 & 8.7 & 8.7 & $(5.7-12.8)$ & 12.0 & $(8.6-16.4)$ & 10.4 & $(8.1-13.3)$ \\
\hline \multirow[t]{5}{*}{ United States } & General population (28) & 14.8 & 13.8 & 14.3 & 14.7 & $(12.8-16.5)$ & 13.1 & $(11.4-14.8)$ & 13.9 & $(12.6-15.2)^{c}$ \\
\hline & Non-Hispanic Whites (28) & - & - & - & 13.9 & $(11.3-16.5)$ & 11.5 & $(9.1-13.9)$ & 12.7 & $(11.0-14.5)^{\mathrm{c}}$ \\
\hline & Non-Hispanic Blacks (28) & - & - & - & 19.5 & $(15.3-23.7)$ & 20.1 & $(15.9-24.4)$ & 19.8 & $(16.8-22.8)^{c}$ \\
\hline & Mexican-Americans (28) & - & - & - & 24.0 & $(19.4-28.6)$ & 27.5 & $(22.6-32.3)$ & 25.7 & $(22.4-29.1)^{c}$ \\
\hline & Pima Indians (30) & - & - & - & 50.2 & $(47.8-52.7)$ & 52.6 & $(50.3-54.9)$ & 51.4 & $(49.7-53.1)^{c}$ \\
\hline \multicolumn{11}{|l|}{ Caribbean } \\
\hline Barbados & Bridgetown (31) & 15.0 & 18.0 & 17.0 & 15.9 & $(10.6-22.9)$ & 16.9 & $(12.5-22.3)$ & 16.4 & $(13.1-20.5)$ \\
\hline \multirow[t]{2}{*}{ Cuba } & Santiago (32) & 1.5 & 6.6 & $4.6(1.2-8.0)$ & & - & & - & & - \\
\hline & Havana (33) & - & - & 14.8 & & - & & - & 11.8 & $(8.3-16.3)$ \\
\hline Guadeloupe & Guadeloupean (34) & - & - & $5.8(4.4-7.2)$ & & & & & & \\
\hline \multirow{2}{*}{ Jamaica } & Jamaican (6) & - & - & 17.9 & & - & & - & 11.1 & $(9.7-12.3)^{d}$ \\
\hline & Spanish Town (35) & $9.8(7.2-12.4)$ & $15.7(13.1-18.3)$ & $13.4(11.5-15.2)$ & 9.5 & $(7.0-12.0)$ & 15.7 & $(13.2-18.3)$ & 12.6 & $(10.8-14.4)^{c}$ \\
\hline Trinidad \& Tobago & St. James (36) & 11.9 & 14.9 & 13.2 & 11.6 & $(9.8-13.3)$ & 13.9 & $(11.8-16.1)$ & 12.7 & $(11.4-14.1)^{\mathrm{C}}$ \\
\hline \multicolumn{11}{|l|}{ South America } \\
\hline \multirow[t]{2}{*}{ Argentina } & La Plata (38) & & & 5.0 & & - & & - & & - \\
\hline & Avellaneda (39) & 10.1 & 7.4 & 8.1 & & - & & - & 7.6 & $(5.6-10.1)^{d}$ \\
\hline Bolivia & Four cities (8) & $6.8(6.2-8.3)$ & $7.6(6.3-8.9)$ & $7.2(6.2-8.3)$ & 8.2 & $(6.5-9.9)$ & 9.1 & $(7.6-10.5)$ & 8.6 & $(7.5-9.7)^{c}$ \\
\hline \multirow[t]{4}{*}{ Brazil } & Nine cities (40) & $7.5^{\mathrm{e}}$ & $7.6^{\mathrm{e}}$ & $7.6^{\mathrm{e}}$ & & - & & - & & - \\
\hline & Rio de Janeiro (41) & 5.7 & 9.9 & 7.6 & 5.7 & $(4.2-7.3)$ & 9.4 & $(7.8-11.1)$ & 7.6 & $(6.4-8.7)^{c}$ \\
\hline & São Paulo, Issei (42) & & & $12.8^{\mathrm{e}}$ & & - & & - & & - \\
\hline & São Paulo, Nisei (42) & & & $16.2^{\mathrm{e}}$ & & & & & & - \\
\hline \multirow[t]{5}{*}{ Chile } & Santiago (45) & 5.8 & 7.7 & 6.5 & 8.4 & $(5.6-12.1)$ & 5.7 & $(4.0-7.7)$ & 7.0 & $(5.5-8.9)$ \\
\hline & Valparaíso (44) & 4.0 & 3.8 & 3.9 & & - & & - & & - \\
\hline & Mapuche (45) & 0.4 & 1.4 & 1.0 & & - & & - & & - \\
\hline & Mapuche (46) & $3.2(0.7-9.0)$ & $4.5(2.2-8.1)$ & $4.1(2.2-6.9)$ & & - & & - & & - \\
\hline & Aymara (47) & & & $1.5(0.3-4.5)$ & & - & & - & & - \\
\hline Colombia & Urban (7) & 7.3 & 7.4 & - & 7.7 & $(4.2-13.0)$ & 8.7 & $(4.8-14.6)$ & 8.2 & $(5.4-12.0)$ \\
\hline Paraguay & Urban (48) & 5.5 & 6.5 & 6.5 & 7.2 & $(4.9-10.6)$ & 7.1 & $(5.6-9.1)$ & 7.2 & $(5.9-8.8)$ \\
\hline Peru & Three zones (49) & - & - & $4.8(3.2-7.0)$ & - & - & - & & & \\
\hline \multirow[t]{4}{*}{ Suriname } & Main ethnic groups (50) & - & - & - & 7.5 & $(4.6-11.6)$ & 9.9 & $(6.6-14.3)$ & 8.7 & $(6.4-11.6)$ \\
\hline & Creoles $(50)$ & 7.0 & 4.0 & - & 6.3 & (3.1-11.3) & 13.3 & $(9.1-19.6)$ & 9.8 & $(7.0-13.3)$ \\
\hline & East Indians (50) & 11.0 & 11.0 & - & 12.1 & $(7.1-19.4)$ & 13.3 & $(8.7-19.6)$ & 12.7 & $(9.2-17.2)$ \\
\hline & Indonesians (50) & 2.0 & 3.0 & - & 4.2 & $(1.3-9.8)$ & 3.0 & $(1.2-6.1)$ & 3.6 & $(1.9-6.3)$ \\
\hline Uruguay & Urban-rural (51) & 6.8 & 6.9 & 6.9 & & - & & - & & - \\
\hline \multirow{3}{*}{ Venezuela } & Urban (51) & 4.5 & 9.4 & 7.3 & & & & & & \\
\hline & Urban (52) & - & - & 4.4 & & - & & - & & - \\
\hline & Mérida (53) & - & - & 3.8 & & - & & - & & - \\
\hline
\end{tabular}

a Standardized using the world population (10)

b $95 \%$ confidence intervals based on the Poisson distribution.

c $95 \%$ confidence intervals based on a normal distribution.

d Standardized by age.

e Standardized by the authors. 
TABLE 4. Adjusted diabetes prevalence rates ${ }^{a}(\%)$ among individuals 34-64 years of age in selected countries of Latin America and the Caribbean

\begin{tabular}{|c|c|c|c|c|c|c|c|}
\hline \multirow[b]{2}{*}{ Country } & \multirow[b]{2}{*}{ Population, reference } & \multicolumn{6}{|c|}{ Adjusted rate $(95 \% \mathrm{Cl})^{\mathrm{b}}$} \\
\hline & & & Male & & Female & & Both \\
\hline Mexico & Mexico City (27) & 11.9 & $(8.0-17.2)$ & 17.9 & $(13.5-23.5)$ & 14.9 & $(11.9-18.6)$ \\
\hline Trinidad and Tobago & St. James (36) & 9.3 & (7.7-10.9) & 12.5 & $(10.4-14.5)$ & 10.9 & $(9.6-12.1)^{c}$ \\
\hline Argentina & La Plata (37) & 3.4 & $(1.5-6.7)$ & 2.6 & $(1.0-5.7)$ & 3.0 & $(1.6-5.1)$ \\
\hline Bolivia & Four cities (9) & 9.5 & $(7.2-11.8)$ & 10.6 & $(8.6-12.7)$ & 10.1 & $(8.5-11.6)^{c}$ \\
\hline Brazil & Rio de Janeiro (40) & 6.0 & $(4.8-7.6)$ & 9.7 & $(7.7-12.1)$ & 7.9 & $(6.7-9.2)$ \\
\hline Paraguay & Urban (46) & 7.6 & $(4.9-11.3)$ & 8.6 & $(6.2-10.9)$ & 8.9 & $(6.3-10.0)$ \\
\hline Suriname & All races (47) & 7.3 & $(4.3-11.6)$ & 8.7 & $(6.0-10.6)$ & 8.0 & $(6.0-10.6)$ \\
\hline
\end{tabular}

a Truncated rate adjusted using the world population (10) by the direct method.

b $95 \%$ confidence intervals based on the Poisson distribution.

c $95 \%$ confidence intervals based on a normal distribution.

and disability among young adults make this disease a considerable burden to society (54-57). Public health actions to ensure access to quality care in this population are urgently needed.

Although type 2 diabetes appears with more frequency in people over 40 years of age, there are reports showing a growing prevalence of this clinical type among children in various segments of the United States population (58-61). It is not clear whether this phenomenon is already occurring in LAC, but it is anticipated that a similar trend will emerge unless prevention strategies are introduced in the LAC nations.

Of special note are the prevalence rates of diabetes mellitus observed among native American populations and other ethnic and minority groups in the various countries of the Americas. In the state of Arizona in the United States, more than half of the adult Pima Indians are known to have diabetes, and other Native Americans from the United States and Canada also have an increased prevalence of diabetes. Other ethnic and minority groups in the United States, such as Mexican-Americans and non-Hispanic blacks, are also disproportionately affected by diabetes (28).

In most urban populations of Latin America and the Caribbean, the prevalence of diabetes among adults is between $6 \%$ and $8 \%$. While the Mapuche Indians of Chile were practically free of diabetes in 1985, they showed prevalence rates of $3.2 \%$ among males and $4.5 \%$ among females in 2000 . These results suggest that an acculturation process, with the predominance of a lack of physical activity and a hypercaloric diet, may be occurring in this native community, and the same process may be occurring across Latin America.

It is evident from the results of various surveys in LAC that diabetes is particularly affecting people from the lower socioeconomic classes, as evidenced by higher prevalence rates for people with lower educational levels in Bolivia (8) and in Jamaica (6). This may be because of higher exposure to major risk factors such as hypercaloric diet, low physical activity, and obesity.
According to new evidence from the Finnish Diabetes Prevention Study (62) and elsewhere, more than half of the diabetes cases can be prevented among those at higher risk. Diabetes prevention and control programs are urgently needed and are potentially cost-effective strategies that can reduce the huge burden of diabetes (63). Disease control programs should address the comparatively higher prevalence of diabetes reported among women, the less educated, and low-income populations in the Americas. Despite economic constraints, there is a clear need for intervention. A coordinated action plan to deal with the current epidemic of diabetes is critical in order to take the available technological advances in the field of diabetes prevention and control and to translate them into affordable public health actions.

Acknowledgements. The authors would like to thank Maureen Harris and Peter Bennett for their support in providing data for the completion of this paper.

\section{REFERENCES}

1. King H, Aubert RE, Herman WH. Global burden of diabetes, 1995-2025. Diabetes Care 1998;21:1414-1431.

2. World Health Organization. Diabetes mellitus: report of a WHO study group on diabetes mellitus. Geneva: WHO; 1985. (WHO Technical Report Series No. 727).

3. Expert Committee on the Diagnosis and Classification of Diabetes Mellitus. Report of the Expert Committee on the Diagnosis and Classification of Diabetes Mellitus. Diabetes Care 1997;20:1183-1197.

4. World Health Organization. Definition, diagnosis and classification of diabetes mellitus and its complications: report of a 
WHO consultation. Geneva: WHO; 1999. (WHO/NCD/NCS 99.2).

5. Expert Committee on the Diagnosis and Classification of Diabetes Mellitus. Report of the Expert Committee on the Diagnosis and Classification of Diabetes Mellitus. Diabetes Care 2000; 23(Supp 1):54-55.

6. Ragoobirsingh D, Lewis-Fuller E, Morrison EY. The Jamaican Diabetes Study: a protocol for the Caribbean. Diabetes Care 1995;18(9):1277-1279.

7. Aschner P, King H, Triana de Torrado M, Marina Rodriguez B. Glucose intolerance in Colombia: a population-based survey in an urban community. Diabetes Care 1992;16(1):90-93.

8. Barceló A, Daroca MC, Rivera R, Duarte E, Zapata A. Diabetes in Bolivia. Rev Panam Salud Publica 2001;10(5):318-323.

9. Metzger BE, Coustan DR, eds. Proceedings of the Fourth International Workshop-Conference on Gestational Diabetes Mellitus. Diabetes Care 1998;21(Suppl 2):B1-B167.

10. Segi M. Cancer mortality for selected sites in 24 countries (1950-57). Sendai: Tohuku University School of Medicine; 1960.

11. King H, Rewers M. Global estimates for prevalence of diabetes mellitus and impaired glucose tolerance in adults. WHO Ad Hoc Diabetes Reporting Group. Diabetes Care 1993;16(1):157-177.

12. WHO Multinational Project for Childhood Diabetes. WHO Diamond Project Group. Diabetes Care 1990;11(10):1062-1068.

13. Karvonen M, Viik-Kajander MV, Moltchanova E, Libman I, LaPorte R, Tuomilehto J. Incidence of childhood type 1 diabetes worldwide. Diabetes Mondiale (DiaMond) Project Group. Diabetes Care 2000;23:1516-1526.

14. Diabetes Epidemiology Research International Group. Geographic patterns of childhood insulin-dependent diabetes mellitus. Diabetes 1988;37:1113-1119.

15. Amos AF, McCarty DJ, Zimmet P. The rising global burden of diabetes and its complications: estimates and projections to the year 2010. Diabet Med 1997;14(Suppl 5):S1-S85.

16. Siemiatycki J, Colle E, Aubert D, Campbell S, Belmonte MM. The distribution of type 1 (insulin-dependent) diabetes mellitus by age, sex, secular trend, seasonality, time clusters and space-time cluster: evidence from Montreal 1971-1983. Am J Hygiene 1986;124:545-560.

17. Blanchard J, Dean H, Anderson K, Wajda A, Ludwig S, Depew N. Incidence and prevalence of diabetes in children aged 0-14 years in Manitoba, Canada, 19851993. Diabetes Care 1997;20(4):512-515.

18. LaPorte R, Matsushima M, Yue-Fong Chang. Prevalence and incidence of insulin-dependent diabetes mellitus. In: National Diabetes Data Group. Diabetes in America. Bethesda, Maryland, United States of America: National Institutes of Health; 1995. pp. 34-46. (NIH Publication No. 951468).

19. Fraser de Llado TE, González de Pijem L, Hawk B. Incidence of IDDM in children living in Puerto Rico. Puerto Rican IDDM Coalition. Diabetes Care 1998;21(5):744746.

20. Tull ES, Jordan OW, Simon L, Laws M, Smith DO, Vanterpool $\mathrm{H}$, et al. Incidence of childhood-onset IDDM in Black African-heritage populations in the $\mathrm{Ca}$ ribbean. The Caribbean African Heritage IDDM Study (CAHIS) Group. Diabetes Care 1997;20(3):309-310.

21. Lisboa HRK, Graebin R, Butzke L, Rodriguez CS. Incidence of type 1 diabetes mellitus in Passo Fundo, RS, Brazil. Brazilian J Med Biol Res 1998;31:1553-1556.

22. Carrasco E, Pérez F, Calvillán C, López G, Wolff C, Castaño A, et al. Incidencia de diabetes mellitus insulino dependiente en Santiago de Chile (1990-1993). Rev Med Chile 1996;124:561-566.

23. Carrasco E, Pérez F, Santos JL, López G, Calvillan M, Wolff $C$, et al. One of the lowest validated incidence rates of insulin-dependent diabetes mellitus in the Americas: Santiago, Chile. Diabetes Res Clin Pract 1996;34 Suppl:S153-S157.

24. Health Canada. Diabetes in Canada. Ottawa: Laboratory Center for Disease Control; 1999.

25. Delisle HF, Rivard M, Ekoe JM. Prevalence estimates of diabetes and other cardiovascular risk factors in the two largest Algonguin communities of Quebec. Diabetes Care 1995;18(9):1255-1259.

26. Stern MP, Gonzalez C, Mitchell BD, Villapando E, Haffner SM, Hazuda HP. Genetic and environmental determinants of type II diabetes in Mexico City and San Antonio. Diabetes 1992;41:484-492.

27. Posadas-Romero C, Yamamoto-Kimura L, Lerman-Garber I, Zamora-Gonzalez J, Fajardo-Gutierrez A, Velazquez L, et al. The prevalence of NIDDM and associated coronary risk factors in Mexico City. Diabetes Care 1994;17(12):1441-1448

28. Harris MI, Flegal KM, Cowie CC, Eberhard MS, Goldstein D, Little RR, et al. Prevalence of diabetes, impaired fasting glucose, and impaired glucose tolerance in U.S. adults: the third National Health and Nutrition Examination Survey, 1988-1994. Diabetes Care 1998;21(4): 518-524.

29. Knowler WC, Bennett PH, Hamman RP, Miller M. Diabetes incidence and prevalence in Pima Indians: a 19-fold greater incidence than in Rochester, Minnesota. Am J Epidemiol 1978;108(6):497-505.

30. Knowler WC, Saad MF, Petitt DJ, Nelson RG, Bennett PH. Determinants of diabetes mellitus in the Pima Indians. Diabetes Care 1993;16(1):216-227.

31. Foster C, Rotimi C, Fraser H, Sundarum C, Liao Y, Gibson E, et al. Hypertension, diabetes, and obesity in Barbados: findings from a recent population-based survey. Ethn Dis 1993;3(4):404-412.

32. Salvador Álvarez MJ, Pérez Paz HM. Prevalencia de diabetes mellitus en la población adulta de un área de salud del municipio de Santiago de Cuba. Rev Cub Epidemiol 1987;25(21):205-213.

33. Díaz-Díaz O, Hernández M, Collado F, Seuc A, Márquez A. Prevalencia de dia- betes mellitus y tolerancia a la glucosa alterada, sus cambios en 20 años en una comunidad de Ciudad de la Habana. Primera reunión científica conjunta GLED/ EDEG, Programa Científico, Buenos Aires, Argentina, 1999.

34. Mouter JP, Kangambeza-Nouvier P, Donnet JP, Pileire B, Echvege E, Patterson AW. Diabetes mellitus and public health in Guadeloupe. West Indian Med J 1990; 39(3):139-143.

35. Wilks R, Rotimi C, Bennett F, McFarlaneAnderson N, Kaufman JS, Anderson SG et al. Diabetes in the Caribbean: results of a population survey from Spanish Town Jamaica. Diab Med 1999;16:875-883.

36. Beckles, GLA. Diabetes mellitus and hypertension: prevalence and mortality risk in urban Trinidad (The St. James cardiovascular survey 1977-85). In: Caribbean Workshop on Standardization of Diabetes Mellitus and Hypertension in the Community. The control of hypertension in the Caribbean community. Bridgetown: Pan American Health Organization; 1988. pp. 38-53.

37. Morice A, Roselló M, Arauz AG, Sánchez G, Padilla G. Diabetes mellitus in Costa Rica. Serie de Documentos Técnicos. San José: INCIENSA; 1999.

38. Hernández RE, Cardonet LJ, Libman C, Gagliardino JJ. Prevalence of diabetes in an urban population of Argentina. Diabetes 1984;81:18-20.

39. de Sereday M, Di Toro CH, Correa A, Nusimovich B, Kapeluschnik D. Encuesta de prevalencia de diabetes: metodología y resultados. Bol Oficina Sanit Panam 1979; 86(4):293-305.

40. Malerbi DA, Franco LJ. The Brazilian Cooperative Group on The Study of Diabetes Prevalence. Multicenter study of the prevalence of diabetes mellitus and impaired glucose tolerance in the urban Brazilian population aged 30-69 yr. Diabetes Care 1992;15(11):1509-1516.

41. Oliveira JEP, Milech A, Franco LJ. The prevalence of diabetes in Rio de Janeiro Brazil. Diabetes Care 1996;19(6):663-665.

42. Franco LJ. Diabetes in JapaneseBrazilians: influence of the acculturation process. Diabetes Res Clin Pract 1996;34(Suppl):S51-S55

43. Mella I, García de los Ríos M, Parker M Covarrubias A. Prevalencia de la diabetes mellitus: una experiencia en grandes ciudades. Bol Oficina Sanit Panam 1983, 94(2):157-165.

44. Jadue L, Vega J, Ecobar MC, Delgado I, Garrido C, Lastra P, et al. Factores de riesgo para las enfermedades no transmisibles: metodología y resultados globales de la encuesta de base del programa CARMEN. Rev Med Chile 1999;127:1004-1013.

45. Larenas G, Arias G, Espinosa O, Charles $M$, Lan-Daeta $O$, Villanueva $S$, et al. Prevalencia de diabetes mellitus en una comunidad Mapuche de la IX región Chile. Rev Med Chile 1985;113:1121-1125.

46. Pérez-Bravo F, Carrasco E, Santos JL, Calvillan M, Larenas G, Albala C. Prevalence of type 2 diabetes and obesity in 
rural Mapuche population from Chile. Nutrition 2001;17(3):236-238.

47. Santos JL, Perez Bravo F, Carrasco E, Calvillan M, Albala C. Low prevalence of type 2 diabetes despite a high average body mass index in the Aymara natives from Chile. Nutrition 2001;17:305-309.

48. Jiménez JT, Palacios M, Cañete $F$, Barrio Canal LA, Medina U, Figueredo R, et al. Prevalence of diabetes mellitus and associated cardiovascular risk factors in an adult urban population in Paraguay. Diabetic Medicine 1998:15:334-338.

49. Seclen S, Leey J, Villena A, Herrera B, Menacho JC, Carrasco A, et al. Prevalencia de diabetes mellitus, hipertensión arterial, hipercolesterolemia y obesidad, como factores de riesgo coronario y cerebrovascular en población adulta de la costa, sierra y selva del Perú. Lima: Colegio Médico del Perú; 1997.

50. Schaad JDG, Terpstra J, Oemrawsingh I, Nieuwenhuijzen Kruseman AC, BouwhuisHoogerwerf MI. Diabetes prevalence in the three main ethnic groups in Surinam (South America): a population survey. Neth J Med 1985;28:17-20.

51. West KJ, Kalbfleisch JM. Glucose tolerance, nutrition and diabetes in Uruguay, Venezuela, Malaysia and East Pakistan. Diabetes 1966;15:9-18.

52. Nucete HJ, Mendoza SG, Romero P, Somoza B, Zerpa A. Diabetes mellitus en algunas poblaciones del estado de Mérida, Venezuela. Acta Científica Venezolana 1980:31:588-592.

53. Pérez Carrillo JC, Cortes Mogollón MP, Henríquez Villalba FM, Lira Cabrera C,
Chacín Álvarez LF. Prevalencia de diabetes mellitus y otros factores de riesgo cardiovascular en la región central de Venezuela. Archivo Hospital Vargas 1997; 39(3-4):123-128

54. Collado-Mesa F, Díaz-Díaz O, MeliánTorres R, Suárez-Pérez R, Vera-González M, Aldana-Padilla D. Mortality of childhood-onset IDDM patients: a cohort study in Havana City Province, Cuba. Diabetes Care 1997;20(8):1237-1241.

55. Diabetes Epidemiology Research International Study. International analysis of insulin-dependent diabetes mellitus: a preventable mortality perspective. Am J Epidemiol 1996;142(6):612-618.

56. Dorman JS, LaPorte RE, Kuller LH, Cruickshanks KJ, Orchard TJ, Wagener DK, et al. The Pittsburgh insulin-dependent diabetes mellitus (IDDM) morbidity and mortality study: mortality results. Diabetes 1984;33:271-276

57. Kostraba JN, Klein R, Dorman JS, Becker DJ, Drash AL, Maser RE, et al. The epidemiology of diabetes complications study. IV. Correlates of diabetic background and proliferative retinopathy. Am J Epidemiol 1991;133(4):381-391.

58. Fagot-Campagna A, Burrows NR, Williamson DF. The public health epidemiology of type 2 diabetes in children and adolescents: a case study of American Indian adolescents in the Southwestern United States. Clin Chim Acta 1999. 286(1-2):81-95.

59. Fagot-Campagna A, Pettitt DJ, Engelgau MM, Burrows NR, Geiss LS, Valez R, et al. Type 2 diabetes among North American children and adolescents: an epidemiologic review and a public health perspective. J Pediatr 2000;136(5):664-672.

60. Dabelea D, Hanson RL, Bennett PH, Roumain J, Knowler WC, Pettitt DJ. Increasing prevalence of type II diabetes in American Indian children. Diabetologia 1998;41:904-910.

61. Neufeld ND, Raffel LJ, Landon C, Chen YD, Valdheim CM. Early presentation of type 2 diabetes in Mexican-American youth. Diabetes Care 1998;21(1):80-86.

62. Tuomilehto J, Lindstrom J, Erikson J, Valle TT, Hamalainen H, Ilanne-Parikka $\mathrm{P}$, et al. Prevention of type 2 diabetes mellitus by changes in lifestyle among subjects with impaired glucose tolerance. $\mathrm{N}$ Engl J Med 2001;344(18):1343-1350.

63. Gagliardino JJ, Echegoyen G. A model educational program for people with type 2 diabetes: a cooperative Latin American implementation study (PENID-LA). Diabetes Care 2001;24:1001-1007.

Manuscript received 26 July 2001. Revised version accepted 7 October 2001.

RESUMEN Objetivo. Describir la incidencia y prevalencia de la diabetes sacarina en el continente americano, de acuerdo con los resultados de una revisión exhaustiva de la literatura publicada acerca de este tema.

\section{Incidencia y prevalencia de la diabetes en América}

Métodos. Los datos se obtuvieron mediante una completa revisión de las bases de datos MEDLINE y BIREME. Además se contactaron las organizaciones gubernamentales y no gubernamentales y otras instituciones para identificar las publicaciones gubernamentales y los informes de conferencias y reuniones. Las tasas de incidencia y prevalencia se ajustaron por edad y sexo, utilizando, siempre que fuera posible, el método directo, con la población de Segi como estándar. Los intervalos de confianza del 95\% se calcularon utilizando la distribución de Poisson o la distribución normal.

Resultados. La diabetes constituye un importante problema de salud pública en América y hay pruebas de que su prevalencia está aumentando en algunos países.

Conclusiones. Dado que la mayoría de los países latinoamericanos y caribeños están sufriendo una transición demográfica, es de esperar que la prevalencia de la diabetes siga aumentando rápidamente en un futuro próximo. Pese a las limitaciones económicas de muchos países, hay una evidente necesidad de realizar un mayor esfuerzo en el campo de la prevención y control de la diabetes. 